\title{
Statyba
}

\section{EXPERIMENTAL DETERMINING OF TIME AND TEMPERATURE STRENGTH PARAMETERS ON WHICH CALCULATIONS OF FIRE RESISTANCE CAN BE BASED}

\section{Z. Bednarek}

To cite this article: Z. Bednarek (1995) EXPERIMENTAL DETERMINING OF TIME AND TEMPERATURE STRENGTH PARAMETERS ON WHICH CALCULATIONS OF FIRE RESISTANCE CAN BE BASED, Statyba, 1:1, 48-58, DOI: 10.1080/13921525.1995.10531501

To link to this article: https://doi.org/10.1080/13921525.1995.10531501

Published online: 26 Jul 2012.

Submit your article to this journal $₫$

Џ Article views: 82 


\section{LAIKO IR TEMPERATŪROS PARAMETRŲ, TAIKOMŲ SKAIČIUOTI ATSPARUMĄ UGNIAI, EKSPERIMENTINIS NUSTATYMAS}

\section{Z. BEDNAREK}

\section{1. İvadas}

Konstrukcijos atsparumas ugniai dažniausiai grindžiamas bandymais nustatyta konstrukciniụ medžiagų kritine temperatūra. Pavyzdžiui, laisvai atremtu perdangos plokščių atsparumas ugniai sutapatinamas su laiku, per kurị tempiamoji armatūra standartinio gaisro metu pasiekia kritinę temperatūrą. Šiuo metu taikomame skaičiavimo modelyje irimo kriterijus sutapatinamas su laikomosios galios netekimu dèl plastinių savybių pasireiškimo tempiamos armatūros labiausiai apkrautame skerspjūvyje, t.y. kada įtempimai armatūroje pasiekia plieno, iš kurio ji pagaminta, takumo ribą $R_{e}^{T}$ temperatūroje $T$. Norint ịvertinti temperatūros kitimo ịtaką, sudaromas $R_{e}^{T}$ arba koeficiento $\varphi=\frac{R_{0,2}^{T}}{R_{e}}$ priklausomybès nuo temperatūros grafikas ( $R_{e}$ - takumo riba normalioje temperatūroje, $R_{0,2}^{T}$ - sąlyginé takumo riba temperatūroje T). Taškai, reikalingi grafikui sudaryti, gaunami atliekant tempimo bandymą pastoviose padidintose ir aukštose temperatūrose.

Šio darbo autoré taiké kitą irimo kriterijų, sutapatindama ji su didžiausiu tempiamos armatūros deformavimosi pagreičiu. Grafiko " $\varepsilon-\tau$ " (deformacija-laikas) kritinis tǎ̌kas, charakterizuojamas didžiausiu deformavimosi pagreičiu, buvo gautas analizuojant antrają išvestinę $\frac{d^{2} \varepsilon}{d \tau^{2}}$. Grafikai " $\varepsilon-\tau$ " buvo sudarinejjami pagal bandymų duomenis, atliktus panašiomis standartinio gaisro sąlygoms.

\section{Bandymų atlikimo sąlygos}

Bandymuose ivertinamas temperatūros pasiskirstymas, artimas gaisro metu atsirandančiam temperatūros pasiskirstymui gelžbetoninès plokštès taškuose, kuriuose yra tempiama armatūra. Temperatūn pasiskirstymas plokštés tūryje ir laike, priklausantis nuo šilumos mainų tarp statybinio elemento ir aplinkos, gautas analitiniu būdu, taikant tam tikrus fizinius bei matematinius modelius ir šilumos laidumo lygčių sprendimo skaitinius Furje metodus. Programa TEMP kompiuteriui, skirta vienmačiam temperatūrų laukui plokšteje nustatyti, kurios viena pusè 


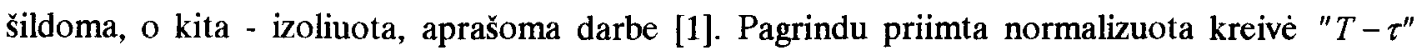
(temperatūra - laikas), aprašyta logaritmine priklausomybe:

$$
T=345 \log (8 \tau+1) \text {, }
$$

kuri apibrězia termines sąlygas bandymo krosnyje nustatant statybinių elementų atsparumą ugniai. Taip gaunamos priklausomybès " $T-\tau$ " tam tikram tempiamos armatūros atstumui $\mathrm{x}$ nuo plokštès apačios. Darbe tiriant ịtempimų armatūroje įtaką plieno stiprumo parametrams buvo panauduota priklausomybé, kaix $=25 \mathrm{~mm}$. Pastovių ịtempimų būvis bandymo metu išreiškiamas santykiniu itemptumu $\alpha_{\sigma}=\sigma / R_{e}$,

kur $\sigma$ - įtempimai bandymo metu,

$R_{e}$ - bandymu nustatyta bandomojo plieno takumo riba. Bandymuose buvo priimta $\alpha_{\sigma}=0,15-1$.

\section{Bandymo eiga}

Bandymo eiga parodyta 1 paveiksle. Šildymas ijungiamas po to, kai bandinio santykinis
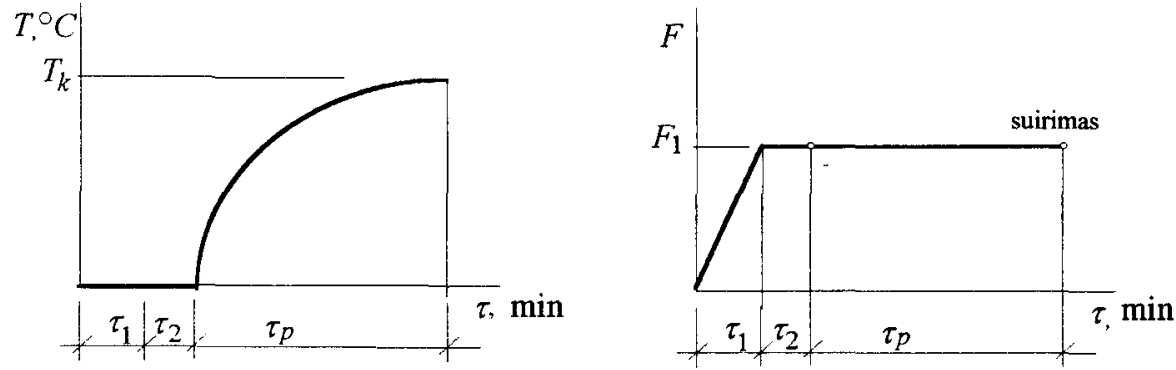

1 pav. Bandymo eigos diagrama; $\tau_{1}$ - laikas, per kuri pasiekiamas norimas apkrovimas,

$\tau_{2}$ - laikas, per kuri pasiekiama $50^{\circ} \mathrm{C}$ temperatūra, $\tau_{p}$ - bandymo laikas

ịtemptumas pasiekia norimą dydị. Per laiką $\tau_{2}$ temperatūra krosnyje pakildavo iki $50^{\circ} \mathrm{C}$. Laikas (bandymo pradžia) būdavo pradedamas skaičiuoti nuo momento, kai temperatūra matavimo taškuose, kuriuose buvo išdesstyti termoelementai, pakildavo iki $50^{\circ} \mathrm{C}$. Tolesnis temperatūros kilimas pagal pasirinktą priklausomybę "temperatūra - laikas" buvo reguliuojamas termoreguliatoriumi. Bandymas baigdavosi trükus bandiniui.. 


\section{Bandymo rezultatai}

\subsection{Atsparumo parametrai}

Atsparumo parametrai nustatomi iš temperatūros ir deformacijų kitimo laike graîikų. Vieno bandinio bandymo metu gauti grafikai $T=f_{1}(\tau)$ ir $\varepsilon=f_{2}(\tau)$ pateikti 2 paveiksle.

Buvo nustatinejami:

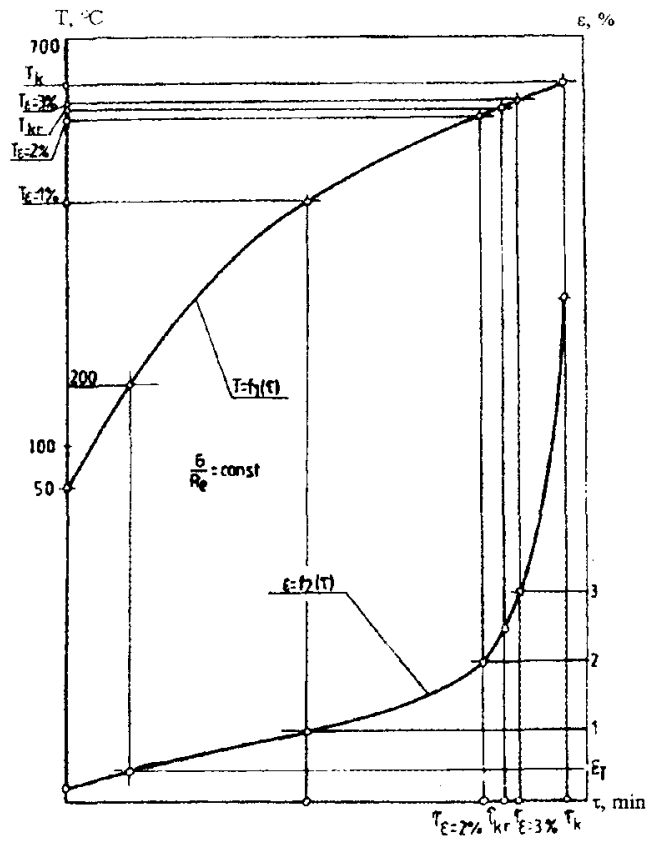

2 pav. Temperatüros ir deformacijos kitimo laike grafikai
1) laiko parametrai:

$\tau_{k}$ - laikas iki bandinio suirimo;

$\tau_{k r}-$ kritinis laikas, skaičiuojamas nuo

bandymo pradžios iki momento, kai

pasiekiamas grafiko " $\varepsilon-\tau$ "kritinis

taškas;

$\tau_{\varepsilon=1 \%}, \tau_{\varepsilon=2 \%}, \tau_{\varepsilon=3 \%}$ - laikas, kai bandinio deformacijos pasiekia 1,2 ir $3 \%$

2) temperatūros parametrai:

$T_{k}$ - temperatūra suirimo momentu;

$T_{k r}$ - kritinè temperatūra, atitinkanti gra-fiko $" \varepsilon-\tau$ " kritinị tašką;

$T_{\varepsilon=1 \%}, T_{E=2 \%}, T_{\varepsilon=3 \%}$ - temperatūros, kuriose bandinio deformacijos pasiekia 1,2 ir $3 \%$

3) deformatyvumo parametrai:

$\varepsilon_{T}$ - deformacija, atitinkanti temperatūrą 200 300,400 ir $500^{\circ} \mathrm{C}$.

Kritiniu grafiko" $\varepsilon-\tau^{\prime \prime}$ tašku laikomas taškas, kuriame yra didžiausias deformacijų greičio prieaugis. Šis taškas nustatomas grafiniu būdu. Pasiekus kritinị tašką, santykinai nedidelis deformaciju greitis $(0,02-0,09 \% / \mathrm{mm}$ priklausomai nuo plieno rūšies) gerokai padideja (apie 5 $\% / \mathrm{min})$, kas pranašauja bandinio trūkimą. Šs taškas fizine prasme charakterizuojamas dideliu medžiagos struktūros pasikeitimu.

Analizuojant aukščiau aprašytus parametrus, gautus bandymu metu, o ypač laiko ir temperatūros parametrus, gauta daug priklausomybių, leidžiančių nustatyti ịtemptumo $\alpha_{\sigma}=\sigma / R_{\varepsilon}$ ịtaką šiems parametrams. Bandiniai pagaminti iš St 3S(A-I klasé), 18G2 (A-II klasé) ir 34GS (AIII klasè) plienų. Tai pagrindiniai plienai, naudojami statybose I enkijos Respublikoje. 


\subsection{Bandymų rezultaty analizė}

Aproksimuojant bandymo rezultatus, gautos priklausomybès, aprašančios plieno atsparumo parametrus. Laiko parametrai - laikas iki suirimo (laiko atsparumas) $\tau_{k}$, kritinis laikas $\tau_{k r}$ ir laikas, kai pasiekiamos 1,2 ir $3 \%$ dydžio deformacijos, $\tau_{\varepsilon}(\varepsilon=1,2,3 \%)$ aprašomi priklausomybe:

$$
\tau=A\left(\sigma / R_{e}\right)^{-0,5}
$$

čia $\tau$ - laiko parametras ( $\min ) ; A$ - medžiagos konstanta, lygi atitinkamam laiko parametrui, nustatomam iš bandymo grafiko " $\varepsilon-\tau$ ", kai $\sigma=R_{e}$. Konstantų $A$ reikšmès, naudotos nustatant $\tau_{k}$ ir $\tau_{k r}$, pateiktos 1 lenteleje.

1 lentelè. Plienų konstantos $A$

\begin{tabular}{|c|c|c|c|}
\hline \multirow{2}{*}{ Parametrai } & \multicolumn{3}{|c|}{ Plieno rūšis } \\
\cline { 2 - 4 } & $\mathrm{St3S}$ & $18 \mathrm{G} 2$ & $34 \mathrm{GS}$ \\
\hline$\tau_{k}$ & 39,78 & 41,49 & 44,08 \\
\hline$\tau_{k r}$ & 34,50 & 38,95 & 41,28 \\
\hline
\end{tabular}

Parametru $\tau_{k}$ ir $\tau_{k r}$ grafikai pateikti 3 ir 4 paveiksluose. Santykinius laiko parametrus $\alpha_{\tau}=\tau / \tau_{e}$ (5 pav.) galima aprašyti priklausomybe $\alpha_{\tau}=\left(\sigma / R_{e}\right)^{-0.5}$, kur $\tau$ - atitinkamas laiko parametras esant įtempimui $\sigma, \tau_{e}$-tas pats parametras, kai $\sigma=R_{e}$.

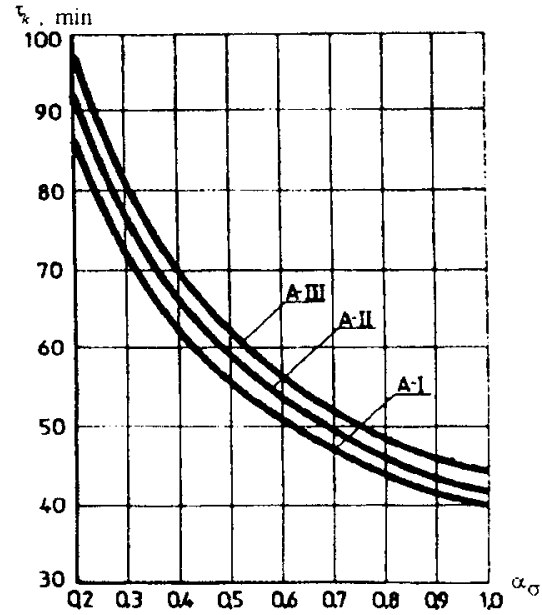

3 pav. Laiko, per kurį bandinys suyra, priklausomybès nuo įtemptumo grafikai

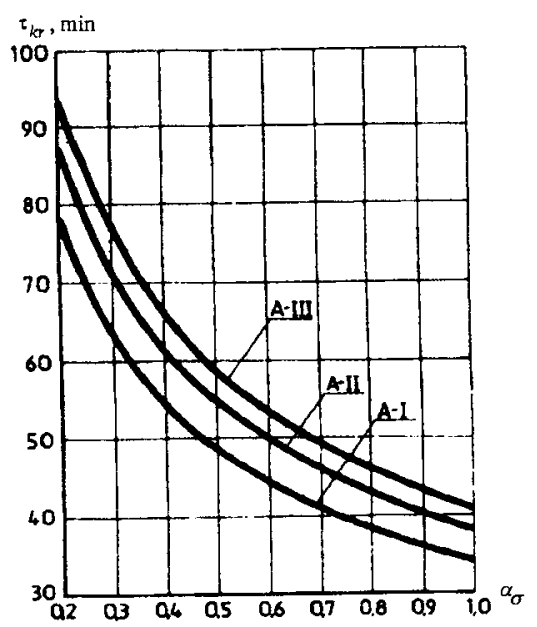

4 pav. Bandinio kritinio laiko priklausomybès nuo itemptumo grafikai 


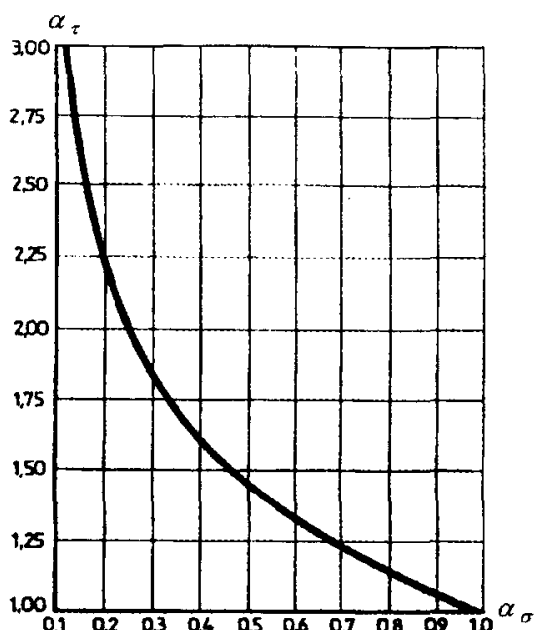

5 pav. Santykinio laiko parametro priklausomybès nuo îtemptumo grafikas
Temperatūriniai parametrai - bandymo pabaigos (suirimo) temperatūra $T_{k}$, kritinè temperatūra $T_{k r}$ ir temperatūra $T_{\varepsilon}$, kai pasiekiamos 1,2 ir $3 \%$ deformacijos, aprašomos priklausomybe:

$$
T=B\left(\sigma / R_{e}\right)^{-0,2}
$$

čia $T$ - temperatūrinis parametras $\left({ }^{\circ} \mathrm{C}\right) ; B$ medžiagos konstanta, lygi atitinkamam temperatūriniam parametrui, kuris nustatomas iš bandymo grafiko " $T-\tau$ ", kai $\sigma=R_{e}$.

Konstantų $B$ reikšmès, kurios buvo naudotos nustatant $T_{k}$ ir $T_{k r}$, pateiktos 2 lenteleje.

2 lentelè. Plienų konstantos $B$

\begin{tabular}{|c|c|c|c|}
\hline \multirow{2}{*}{ Parametrai } & \multicolumn{3}{|c|}{ Plieno rūšs } \\
\cline { 2 - 4 } & $\mathrm{St3S}$ & $18 \mathrm{G} 2$ & $34 \mathrm{GS}$ \\
\hline$T_{k}$ & 538,3 & 543,7 & 549,3 \\
\hline$T_{k r}$ & 506,5 & 529,7 & 534,9 \\
\hline
\end{tabular}

Parametrų $T_{k}$ ir $T_{k r}$ grafikai pateikti 6 ir 7 paveiksluose.

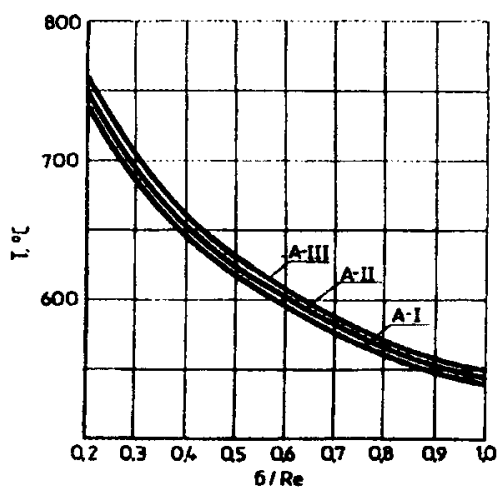

6 pav. Temperatūros $T_{k}$ priklausomybès nuo ¡temptumo grafikai

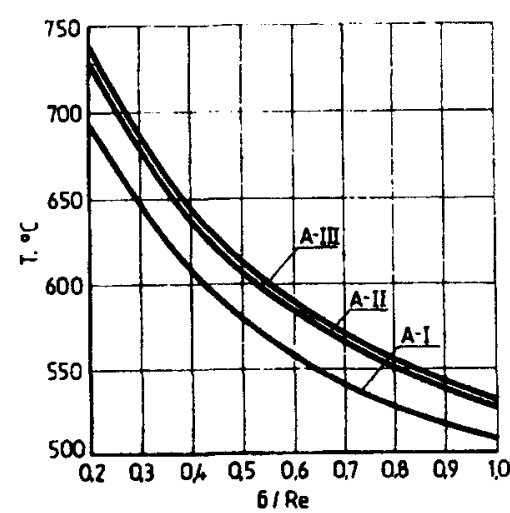

7 pav. Temperatūros $T_{k r}$ priklausomybès nuo itemptumo grafikai 
Siekiant parodyti skirtumus tarp šiuo metu naudojamos ir autorès siūlomos įtempimu ịtakos plieno kritinei temperatūrai nustatymo metodikų, sudaryti grafikai, kurie pateikiami $8-10$ paveiksluose.

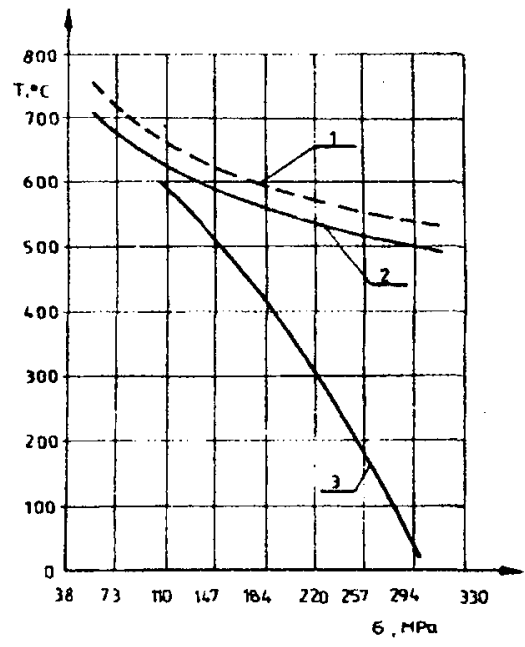

8 pav. Plieno St3S temperatūrinių parametry̨ priklausomybès nuo įtempimų grafikai: 1- temperatūros $T_{k}$ (autorès tyrimai);

2 -temperatūros $T_{k r}$ (autorés tyrimai); 3 - takumo ribos $\left(R_{0,2}\right)$ temperatūros

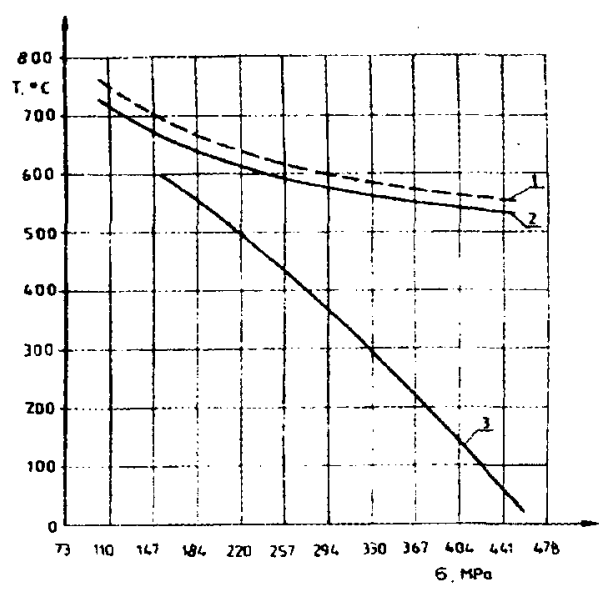

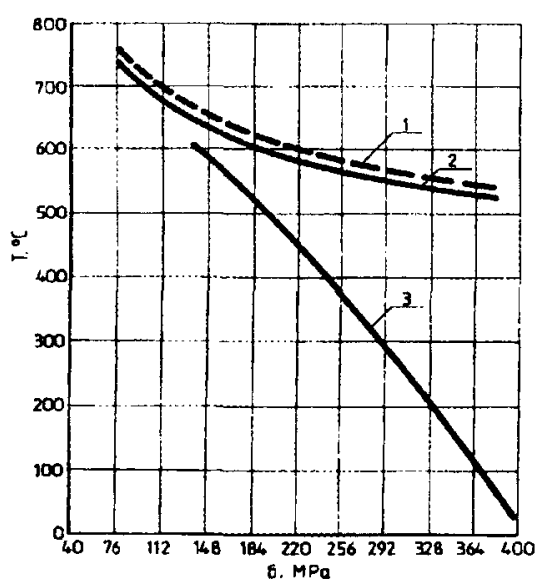

9 pav. Plieno 18G2 temperatūrinių parametry priklausomybès nuo ịtempimų grafikai: 1- temperatūros $T_{k}$ (autorès tyrimai); 2 -temperatūros $T_{k r}$ (autorés tyrimai); 3 - takumo ribos $\left(R_{0,2}\right)$ temperatūros

10 pav. Plieno 34GS temperatūrinių parametru priklausomybés nuo j̇tempimų grafikai: 1- temperatūros $T_{k}$ (autorés tyrimai); 2 -temperatūros $T_{k r}$ (autorés tyrimai); 3 - takumo ribos $\left(R_{0,2}\right)$ temperatüros

5. Terminių sąlygu ịtaka armatūros parametrams, taikomiems skaičiuoti gelžbetoninių elementų atsparumą ugniai

\subsection{Temperatūros pasiskirstymo skaičiavimo modeliuose įvertinimas}

Šiuo metu taikomame skaičiavimo modelyje teigiama, kad plieno stiprumo parametrai, nustatyti statiniais tempimo bandymais padidintose ir aukštose temperatūrose, gerai 
charakterizuoja jo savybes gaisro metu ir gali būti naudojami ịvertinant atsparumą ugniai. Šis teiginys grindžiamas tuo, kad bandymo ugnimi (trunkančio $30-120 \mathrm{~min}$ ) ir statinio tempimo bandymo (trunkančio 20 - 30 min) trukmès panašios. Be to, tempimo bandymo metu neišvengiama reologinių reiškinių ịtakos. Todèl, skaičiuojant atsparumą ugniai, stiprumo parametrai nustatomi neatsižvelgiant ị tikrajị temperatūros pasiskirstymą, t.y. priimama, kad plieno stiprumo savybèms turi įtakos tik temperatūros didumas, bet neturi įtakos jos kilimo eiga ir greitis. Šiluminès dalies skaičiavimuose priimtas pasiskirstymas "temperatūra - laikas" naudojamas nustatyti tik kritinei temperatūrai, t.y. atsparumui ugniai.

Autorès siūlomas skaičiavimo modelis remiasi šiais teiginiais:

- temperatūros pasiskirstymas, o ypač temperatūros kilimo greitis, turi įtakos plieno stiprumo parametrams ir suirimo pobũdžiui;

- ịvairiu rūšiu plienai, taip pat ir statybiniai, pasižymi inercijos savybèmis, dèl kurių sulètėja arba visiškai sustoja dideliu greičiu šildomos medžiagos irimo procesas, t.y. šildymo greitis turi įtakos kritinei temperatūrai;

- iš bandymų, ivykdytų standartinio gaisro sąlygomis paaiškèjo, kad lenkiami elementai, kurių atsparumas ugniai nustatytas pagal šiuo metu priimtą modelị, turi laikomosios galios atsargą pasibaigus laikui, atitinkančiam jų atsparumą ugniai.

\subsection{Terminiu sąlygu ịtakos stiprumo parametrams tyrimas}

Bandymai buvo atliekami esant pastoviam îtemptumui $\alpha_{\sigma}=$ const ir temperatūros pasiskirstymams, parodytiems 11,12 ir 13 paveiksluose, kurie teoriškai atitinka esančius $x=15$, 25,35 ir $75 \mathrm{~mm}$ atstumu nuo gelžbetoninès plokštès apačios.

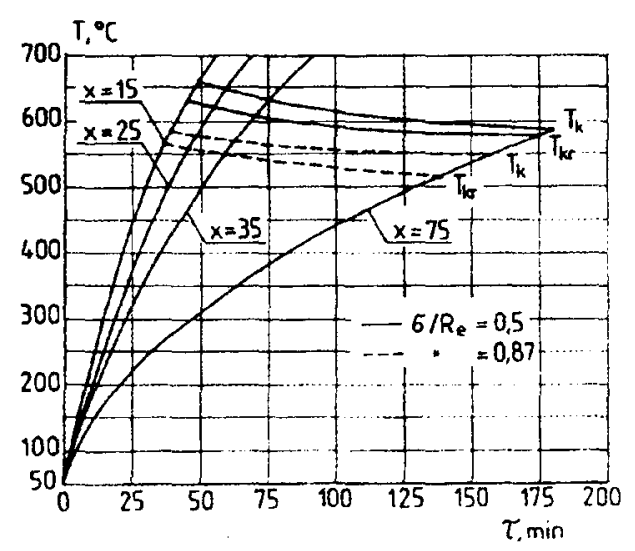

11 pav. Plieno St3S temperatūriniu parametry $T_{k}$ ir $T_{k r}$ priklausomybés nuo pasiskirstymo " $T-\tau^{\prime \prime}$ grafikai

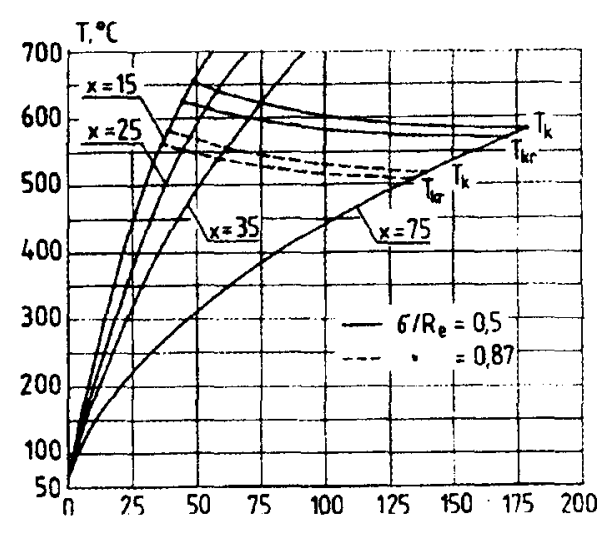

12 pav. Plieno $18 \mathrm{G} 2$ temperatūrinių parametry $T_{k}$ ir $T_{k r}$ priklausomybès nuo pasiskirstymo " $T-\tau$ " grafikai 


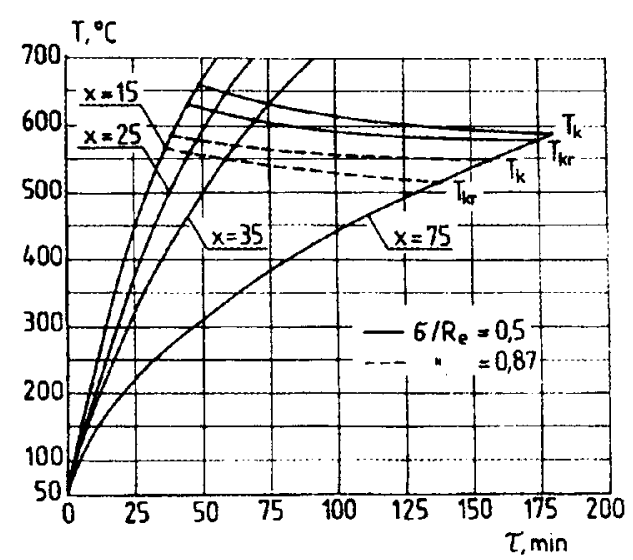

13 pav. Plieno 34 GS temperatūrinių parametrų $T_{k}$ ir $T_{k r}$ priklausomybés nuo pasiskirstymo " $T-\tau$ " grafikai

Pagrindiniai bandymo rezultatai pateikti grafikuose ir lentelèse. 11 - 13 paveiksluose pateiktos kritinès ir bandymo pabaigos temperatūry̨ $\tau_{k r}$ ir $\tau_{k}$ priklausomybès nuo temperatūros pasiskirstymo esant pastoviems ittemptumams $\alpha_{\sigma}=0,5$ ir $\alpha_{\sigma}=0,87$.

Iš rezultatų analizès matyti, kad net esant panašiems (temperatūros kilimo greičio požiūriu) temperatūros pasiskirstymams, pastebimos plieno inercijos savybès; didejant temperatūros kilimo greičiui, kritinè ir pabaigos temperatūros didèja (žr. 11 - 13 pav.). Tai labiau būdinga $18 \mathrm{G} 2$ ir $34 \mathrm{GS}$ plienams negu angliniam St3S plienui .

Pirmiausia buvo siekiama ištirti formulių (2) ir (3) tinkamumą nustatyti laiką iki suirimo $\tau_{k}$, kritinị laiką $\tau_{k r}$, pabaigos temperatūrą $T_{k}$ ir kritinę plieno temperatūrą $T_{k r}$ esant kitiems $(\mathrm{x}=15$, 35 ir $75 \mathrm{~mm}$ ) temperatūros pasiskirstymams.

Bandymo metu gauti laiko parametrai, taip pat jų pagrindu apskaičiuotos St3S plieno konstantos $A$ pateiktos 3 lenteleje. Lyginant dviejų bandymų (kai įtemptumas $\alpha_{\sigma}=0,5$ ir $\alpha_{\sigma}=0,87$ ) metu nustatytas konstantas $A_{1}$ ir $A_{2}$, pastebima, kad jų skirtumai panašūs, kol x=15, 25 ir $35 \mathrm{~mm}$ (skirtumas apie 3\%) ir daugiau (apie 9\%) skiriasi, kai $\mathrm{x}=75 \mathrm{~mm}$.

3 lentelè. St3S plieno laiko parametrai

\begin{tabular}{|c|c|c|c|c|c|}
\hline \multirow{2}{*}{$\alpha_{\sigma}=\sigma / R_{e}$} & \multirow{2}{*}{$\begin{array}{c}\text { Temperatūros } \\
\text { pasiskirstymas }\end{array}$} & \multicolumn{2}{|c|}{ Laiko parametrai (min) } & \multicolumn{2}{|c|}{ Konstantos } \\
\cline { 3 - 6 } 0,5 & $\tau_{k}$ & $\tau_{k r}$ & $A_{1}=\tau_{k} \sqrt{\alpha_{\sigma}}$ & $A_{2}=\tau_{k r} \sqrt{\alpha_{\sigma}}$ \\
\hline \multirow{3}{*}{0,5} & $\mathrm{x}=15$ & 47,0 & 38,0 & 33,2 & 26,9 \\
& $\mathrm{x}=25$ & 56,0 & 47,6 & 39,6 & 33,6 \\
& $\mathrm{x}=35$ & 74,0 & 68,0 & 52,3 & 46,1 \\
& $\mathrm{x}=75$ & 158,0 & 155,0 & 111,7 & 109,1 \\
\hline \multirow{4}{*}{0,87} & $\mathrm{x}=15$ & 35,0 & 31,0 & 32,6 & 28,9 \\
& $\mathrm{x}=25$ & 41,4 & 34,4 & 38,6 & 32,1 \\
& $\mathrm{x}=35$ & 58,0 & 48,0 & 54,1 & 44,6 \\
& $\mathrm{x}=75$ & 132,0 & 130,0 & 123,1 & 121,3 \\
\hline
\end{tabular}

Temperatūriniai parametrai ir ju pagrindu apskaičiuotos St3S plieno konstantos $B_{1}$ ir $B_{2}$ pateiktos 4 lentelèje. Panašūs bandymai buvo atlikti 18G2 ir 34GS plienams. 
4 lentelè. St3S plieno temperatūriniai parametrai

\begin{tabular}{|c|c|c|c|c|c|}
\hline \multirow{2}{*}{$\alpha_{\sigma}=\sigma / R_{e}$} & \multirow{2}{*}{$\begin{array}{c}\text { Temperatūros } \\
\text { pasiskirstymas }\end{array}$} & \multicolumn{2}{|c|}{$\begin{array}{c}\text { Temperatūriniai } \\
\left.\text { parametrai ( }{ }^{\circ} \mathrm{C}\right)\end{array}$} \\
\cline { 3 - 6 } & & $T_{k}$ & $T_{k r}$ & $B_{1}=T_{k}\left(\alpha_{\sigma}\right)^{0,2}$ & $B_{2}=T_{k r}\left(\alpha_{\sigma}\right)^{0,2}$ \\
\hline \multirow{3}{*}{0,5} & $\mathrm{x}=15$ & 640 & 601 & 556,8 & 522,9 \\
& $\mathrm{x}=25$ & 632 & 589 & 549,8 & 512,4 \\
& $\mathrm{x}=35$ & 610 & 579 & 530,7 & 503,7 \\
& $\mathrm{x}=75$ & 588 & 564 & 511,5 & 490,7 \\
\hline \multirow{3}{*}{0,87} & $\mathrm{x}=15$ & 563 & 549 & 546,1 & 532,5 \\
& $\mathrm{x}=25$ & 544 & 522 & 537,7 & 506,3 \\
& $\mathrm{x}=35$ & 534 & 518 & 518,0 & 502,5 \\
& $\mathrm{x}=75$ & 516 & 502 & 500,5 & 486,9 \\
\hline
\end{tabular}

\section{Bandymų rezultatų panaudojimas nustatant gelžbetoninių plokščiu atsparumą ugniai}

Priimama visuotinè ir bandymu patvirtinta prielaida, kad gelžbetoninès plokštès atsparumas ugniai atitinka kritinị laiką $\tau_{k r}$ plieno, iš kurio pagaminta armatūra.

Kritinè temperatūra ir kritinis laikas pradedami nustatyti nuo priklausomybès "temperatūra laikas" tempiamos armatūros išdèstymo gylyje. Tai galima padaryti priimant atitinkamas medžiagos šilumines charakteristikas, pvz., kaip darbe [1], arba priimant bandymo kreivę iš duomenu banko. Paskui nustatomos medžiagos konstantos $A$ ir $B$. Tam reikia atlikti bandymus pasirinkus du arba net vieną ịtemptumo dydį. Konstanta $A$ pirmuoju atveju nustatoma taip: pvz., išbandžius bandinius, kai $\alpha_{\sigma}=0,5$ ir 0,87 , gauti kritiniai laikai $\tau_{k r}^{\prime}$ ir $\tau_{k r}^{\prime \prime}$. Ju pagrindu iš (2) formulès apskaičiuotos konstantos $A$ turi būti vienodos:

$$
A=\tau_{k r}^{\prime} \sqrt{0,5}, \quad A=\tau_{k r}^{\prime \prime} \sqrt{0,87}
$$

Reikšmès gali skirtis todèl, kad ne visi eksperimento taškai priklauso kreivei $\tau_{k r}=A\left(\alpha_{\sigma}\right)^{-0,5}$, bet nutolę (koreliacijos koeficientas yra 0,906 - 0,973 priklausomai nuo plieno rūšies). Todèl imama vidutinè konstantos $A$ reikšmè. Analogiškai elgiamasi ir nustatant konstantą $B$. Kritiniam laikui ir kritinei temperatūrai nustatyti pakanka atlikti 5 bandymus, esant vienam ịtemptumo dydžiui.

Toliau atliekami atsparumo skaičiavimai. Apkrovimas išimties atveju priimamas pagal formulę:

$$
\sum_{i=1}^{n} \gamma_{f i} G_{k i}+\varphi_{0} \sum_{i=1}^{n} \gamma_{f i} Q_{k i}+F_{a}
$$

čia $G_{k}$ - nuolatinès apkrovos charakteringasis intensyvumas;

$Q_{k l}$ - laikinos apkrovos charakteringasis intensyvumas;

$\varphi_{0}$ - apkrovy derinio koeficientas $\left(\varphi_{0}=0,8\right)$;

$\gamma_{f}$ - apkrovu patikimumo koeficientas $\left(\gamma_{f}=1\right)$. 
Ypatingoji apkrova daugeliu atveju neįvertinama (priimama $F_{a}=0$, kaip ir eksperimento metu). Apskaičiuojame tempiamos armatūros įtempimus ir santykinị įtemptumą. Po to nustatome kritinị laiką iš formulès:

$$
\tau_{k r}=A\left(\sigma / R_{e}\right)^{-0.5}
$$

(arba naudojame 4 pav. pateiktą grafiką), kurị sutapatiname su plokštés atsparumu ugniai. Kadangi nebuvo vertinamas laikas, per kuri bandinys ǐsyla iki $50^{\circ} \mathrm{C}$, gautas laikas $\tau_{k r}$ padidinamas $5 \mathrm{~min}$.

Jeigu reikalinga kritinè plokštès temperatūra, pvz., norint patikrinti betono ir plieno sukibimą, tai ją galima apskaičiuoti iš formulés:

$$
T_{k r}=B\left(\sigma / R_{e}\right)^{-0,2}
$$

Konstanta $B$ nustatoma panašiai kaip $A$ naudojant tų pačių bandymų rezultatus.

\section{Išvados}

1. Iš $8-10$ paveiksluose pateiktų grafikų analizés matyti, kad naudojant šiuo metu taikomą skaičiavimo modelį, gaunama laikomosios galios atsarga. Jeigu seksime bandinių elgseną (remiantis šiais ir " $\varepsilon-\tau^{\prime \prime}$ grafikais), tai pasirodys, kad temperatūrose, kurios yra kritinès kai itempimai atitinka plieno takumo ribą, plieno plastinès deformacijos neatsiranda. Grafiko " $\varepsilon-\tau$ " taškai, atitinkantys šias temperatūras ir įtempimus, yra "nepavojingoje" pusèje, charakterizuojamoje nedideliu deformavimosi greičiu, tam tikru atstumu nuo kritinių taškų.

2. Atkreiptinas dèmesys ị visų rưšių plienų elgsenos panašumą priklausomai nuo įtemptumo ir terminių sąlygu. Tai susiję su ịvairių klasių statybinių plienų supanašèjimu ir skirtumų, ypač metalurginių, išnykimu veikiant aukštoms temperatūroms. Iki šiol šis reiškinys buvo pastebimas tik veikiant pastovioms aukštoms temperatūroms. Autorè, vadovaudamasi pačios atliktais bandymais, patvirtina tokio reiškinio buvimą ir standartinio gaisro sąlygomis.

3. Darbe pateiktos plienų konstantų $A$ ir $B$ reikšmès gali būti taikomos skaičiavimuose tik tuo atveju, kai pasiskirstymas "temperatūra - laikas" artimas bandymo pasiskirstymui.

4. Analizuojant bandymų rezultatus, pastebètos medžiagos inertinès savybès, pasireiškiančios temperatūrinių parametru padidèjimu didèjant temperatūros augimo greičiui. Vadinasi, atsparumo parametrams turi ịtakos ne tik temperatūros dydis, bet ir jo pasiekimo eiga.

5. Atlikti bandymai patvirtina formulių (2) ir (3) tinkamumą laiko ir temperatūros parametrams gaisro sąlygomis nustatyti, įvertinant ịtemptumą ir skirtingus temperatūros pasiskirstymus, (nuo $\mathrm{x}=15 \mathrm{~mm}$ iki $\mathrm{x}=75 \mathrm{~mm}$ ), apimančius praktiškai visus galimus temperatūros pasiskirstymo nukrypimus dèl ịvairių priežasčių.

6. Siūlomas formules ir grafikus lengva panauduoti perskaičiuojant esamų lenkiamų elementu (su jau žinomu atsparumu ugniai) atsparumą ugniai, dél tam tikru priežasčiu siekiant jị padidinti. 
7. Statybinių plienų bandymo rezultatai gali būti panaudojami nustatant ir kitų lenkiamų gelžbetoninių elementų, taip pat ir plieninių konstrukcijų atsparumą ugniai.

\section{LITERATŪRA}

1. Z. Bednarek. Studium wpływu nieustalonych warunków termicznych na stosowane przy ocenie bezpieczenstwa pożarowego konstrukcji parametry wytrzymałościowe stali budowlanych. Monografia. Zeszyty Naukowe SGSP, 1992, Nr. 1(10), s. 203.

2. PN-82/B-02000. Obciążenie budowli. Zasady ustalenia wartości. s. 120.

3. Z. Bednarek. Badanie wpływu naprężeń w zbrojeniu rozciąganym na odporność ogniową elementów zginanych. Inżynieria i budownictwo, 1993, Nr. 3, s. 119-122.

\section{EXPERIMENTAL DETERMINING OF TIME AND TEMPERATURE STRENGTH PARAMETERS ON WHICH CALCULATIONS OF FIRE RESISTANCE CAN BE BASED}

\section{Z. Bednarek}

Sum m a ry

The author presents results of his own experiments for determining strength parameters of steel in thermal conditions of fire on which calculations of fire resistance can be based. The author suggests the calculation of the thermal strength parameters on the basis of noncoventional tensile test in thermal conditions described by the "time-temperatures" curve.Test bars were loaded with the constant force, presented as a steady stress level. The author also investigated the influence of various thermal conditions, described by some "time-temperature" curves, on strength parameters. 